\title{
Prevalence of STDs among prostitutes in Czech border areas with Germany in 1997-2001 assessed in project "Jana"
}

\author{
V Resl, M Kumpová, L Černá, M Novák, P Pazdiora
}

Sex Transm Infect 2003;79:e3 (http://www.stijournal.com/cgi/content/full/79/6/e3)

\begin{abstract}
Background: The STD problem emerged in the Czech Republic as a result of geopolitical and social and economic changes in the state. Prostitution is concentrated mainly around border areas with Austria and Germany, contributing to the increase in STDs. The Czech-German project "Jana," based on a project umbrella network of the WHO, was organised.

Objectives: To prevent STDs, including HIV/AIDS, and assessment of STD prevalence in the target group.

Methods: Prostitutes working in night clubs and in the streets and roads of three districts in the West Bohemian Region of the Czech Republic bordering on Germany were studied. Interactions included street work, venereology check up, psychology and sociology counselling, psychological preparation on possible treatment, and continuous and regular contact.

Results: The number of "love clubs" involved in project "Jana" increased from 46 in 1997 to 72 in 2000. Of 561 street girls registered in the project during 1997-2001, there was one HIV positive, every 11 th prostitute had syphilis, and one in 93 women had gonorrhoea, whereas incidence of syphilis in the Czech Republic was 10.2/100 000 and that of gonorrhoea 9.5/100 000 inhabitants in 2001, 31 women had Chlamydia trachomatis urinary tract and genital infection, and 25 were $\mathrm{HBsAg}$ positives. STD frequency revealed in project participants significantly exceeds numbers of STDs in the other inhabitants of the Czech Republic. The majority of prostitutes were foreigners, mostly Ukrainians and Russians.

Conclusion: The situation in the border areas is alarming. The priority must be to concentrate efforts on prevention of spread of venereal diseases in borders of economically disparate states.
\end{abstract}

$\mathrm{S}$ exually transmitted diseases (STDs) have become an emerging problem in the Czech Republic in the past decade. In the 1990s a steep increase in syphilis cases was observed as a result of geopolitical and socioeconomic changes after the end of socialism in 1989. From 1990 to 2000 syphilis incidence increased five times (to 10.0/100 000 inhabitants). ${ }^{1}$ The number of new HIV/AIDS cases remains stable, ${ }^{2}$ whereas gonorrhoea incidence is decreasing. ${ }^{13}$

The social changes in the state brought about reorganisation of the healthcare delivery system from an entirely state delivered one to mostly private health care with a lack of algorithms and sometimes financial resources for STD control; therefore, supervision of STDs was transferred to the state in 1997. The numbers of immigrants and illegal residents, often with STDs, has been increasing in the country; they tend to stay in border regions and work as prostitutes with German and Austrian men as clients.

A venereal check up and treatment of people with no health insurance is based only on the direct payment by the patient. Treatment of some of these patients is financed by non-governmental organisations, the HIV/AIDS budget, and other sources; others are denied treatment.

STD in border areas and project "Jana"

There is an enormous growth of the "erotic industry" in border areas with Germany and Austria as a result of differences in standards of living. Aside from direct cash, the purpose of prostitution is to fund drug habits.

Czech legislation is insufficiently prepared to handle this complicated situation and the earlier established network of STD control is no longer efficient. That is why efforts were increased to find a way to combat STDs in the most critical areas. In the West Bohemian Region, an association of street workers was established by means of a project called "Jana", which operates within the European movement umbrella network of WHO. Similar projects function in border areas of eight European states.

Project "Jana" deals with STD and its prevention in prostitutes in border areas of the Czech Republic within the West Bohemian Region and Germany (Bavaria). Project "Jana", established by the German government of Oberpfalz, Regensburg, in 1997, has been financed by both the Czech and German states.

\section{OBJECTIVES}

The project aims to prevent STD including HIV/AIDS infection in a complex way. The project's task is to spread information about transmission of STD and information about safer sex by means of personal contact as well as printed materials. It aims to create contacts with the target group of the project on a regular basis, including donation of condoms and lubricants, as well as recommendations to test for HIV, syphilis, gonorrhoea, Chlamydia trachomatis, and viral hepatitis B (HBsAg), to map the STD situation in prostitutes operating in the border areas, and partially to gather information on the prostitutes' sociodemographic characteristics and sexual behaviour. In those with a disclosed STD, the goal is to motivate them to respect the treatment algorithm as well have as a more responsible approach to their own health and thus to contribute to cutting the link of epidemic chain of STD spread in the western region of the Czech Republic. This article concentrates on STD monitoring the project participants and gives results of the check up for STDs in prostitutes, and pertinent facts.

\section{SUBJECTS AND SETTING}

Project "Jana" targets prostitutes, their clients, and pimps from both streets and night clubs in three districts of the 
West Bohemian Region of the Czech Republic along the border with Germany-Domažlice, Klatovy, and Tachov. These prostitutes are considered the target group of high risk of STD. Mostly they have no health insurance or documentation, come from countries with outbreaks of syphilis and HIV/AIDS, and they have almost no knowledge of prevention of STD. They migrate, and their fear of criminal consequences prevent them from attending the state healthcare facilities.

\section{METHODS}

The way the project works includes street workers, venereology investigation, psychological and sociological counselling, psychological preparation for possible treatment, and continuous and regular contact. Venereal check up encompasses the following STDs: HIV, HBsAg, syphilis, gonorrhoea, and $C$ trachomatis genitourinary infections. Every prostitute in the project participates on the basis of voluntary attendance, promise of anonymity, consent to participation, and free treatment regardless of health insurance.

In Domažlice project clinic a basic screening for STD is performed together with social counselling. The project is coordinated by the dermatology and venereology department of the Charles University teaching hospital in Pilsen. If any STD is disclosed in a given participant of the project, this person is directed to dermatology and venereology departments, where diagnosis is confirmed, the prostitute is provided with treatment and a consequent follow up, and the case is notified.

\section{RESULTS}

In the beginning of project in 1997, 46 night clubs operating in the above mentioned districts were involved in the project and this number increased to 72 in 2000 . The total number of prostitutes operating in the area covered by project "Jana" is estimated to be around 700, of which $5-10 \%$ work in the streets. These prostitutes have about 2000 clients a day. The number of club prostitutes seems to be rising.

During 1997-2001, 561 prostitutes in total tested for venereal diseases: 31 women in 1997, 217 in 1998, 65 in 1999, 192 in 2000, and 56 prostitutes in 2001. In 2001, the number of prostitutes tested for STD was reduced because of major financial restrictions of the project. Of 561 prostitutes tested, one HIV positive case was reported, 51 cases of syphilis, six of gonorrhoea, 31 of $C$ trachomatis uro-genital infection, and 25 HBsAg positive were identified (table 1). Apart from Czech prostitutes (43\% of 561), 12 different nationalities participated in STD tests and the majority of them were Ukrainians and Russians (fig 1).

The data disclosed in the project are alarming. The project started to work with a specific social group. Its morbidity is higher than that of the general population. It is impossible to get them to attend standard walk-in dermatology and venereology clinics where numbers of diagnosed and noted cases are in accord with laboratory results, and the numbers of treated patients. The project target group keeps avoiding check ups, and any controlling mechanisms. It is impossible

Table 1 STD disclosed in project "Jana" in 1997-2001

\begin{tabular}{lll}
\hline STD & \multicolumn{2}{l}{ Number of cases \% (of 561 tested) } \\
\hline HIV/AIDS & 1 & 0.18 \\
HBsAg positive & 25 & 4.46 \\
Syphilis & 51 & 9.09 \\
Gonorrhoea & 6 & 1.07 \\
Chlamydia trachomatis & 31 & 5.53 \\
\hline
\end{tabular}

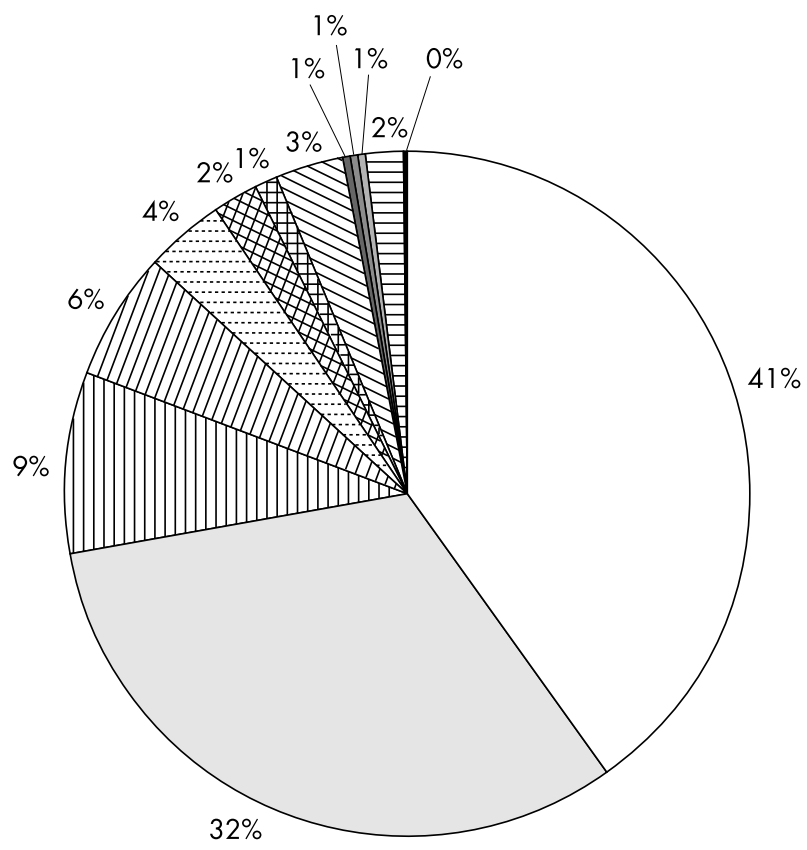

\begin{tabular}{|c|c|c|c|}
\hline & Czech 225 & $D$ Belorussia 12 & Lithuania 2 \\
\hline & Ukraine 180 & \#曲 Bulgaria 6 & Thailand 10 \\
\hline एा & Russia 48 & $\triangle$ Slovakia 18 & Brazil 1 \\
\hline$\overline{D D}$ & Romania 34 & $\square$ Poland 2 & \\
\hline$\cdots$ & Moldavia 21 & Latvia 2 & \\
\hline
\end{tabular}

Figure 1 Proportion of foreigners among the 561 prostitutes involved in project "Jana" in 1997-2001.

to bring them to proper venereology check ups in any other way than by means of tracing and persuading. At present, there is no legislative regulation of prostitution in the Czech Republic.

\section{DISCUSSION}

From 1990s the occurrence of STDs has been rising in the whole of eastern and central Europe, despite the worsening quality of STD notification. ${ }^{2}{ }^{4}$ It is obvious that prevention of HIV/AIDS and STD has to be organised and focused on the spheres with the highest risk of transmission. ${ }^{5}$ Project "Jana" should be understood as a probe to map the STD situation in risk groups. Other projects similar to project "Jana" are planned.

STD numbers assessed in project "Jana" are higher than those for the general population. So far, we have noticed the participation of more than half of foreign prostitutes $(57 \%)$. More than half of the clients are from abroad, but during the past 2 years, participation of Czech men is increasing.

It appears the project is justified. It traced large numbers of infections. Psychological preparation enabled clients to remove the worry of treatment; also, the prostitutes became more responsible in practising safer sex, the chain of the epidemic was broken, and more controls were made possible.

\section{CONTRIBUTORS}

VR: major investigator, supervising the project, organisation and financial matters; MK: processing the data, development of outputs, coordination; LC: streetwork and on-site work director; MN: development of research protocol, on-site work; PP: epidemiological consulting, behavioural part of the project. 


\section{Authors' affiliations}

V Resl, $\mathbf{M}$ Kumpová, $\mathbf{M}$ Novák, Department of Dermatology and

Venereology, Charles University, Pilsen, Czech Republic

L Cerná, Centre for Prevention of HIV/AIDS and Sexually Transmitted

Diseases, Domažlice, Czech Republic

P Pazdiora, Department of Epidemiology, Charles University, Pilsen, Czech Republic

Correspondence to: Professor Vladimír Resl, Dermatovenerologická klinika FN Plzeň, E Beneše 13, 30599 Plzeň, Czech Republic; res|@fnplzen.cz

Accepted for publication 1 September 2003

\section{REFERENCES}

1 Ústav zdravotnické statistiky ČR. Pohlavní nemoci 2000. Praha, 2001;10. [Institute of Medical statistics CR. Venereal disease 2000. Prague].

2 Brưčková M, Malý M, Vandasová J, et al. Zprávy Centra epidemiologie a mikrobiologie [News of the Centre of Epidemiology and Microbiology]. 2002;11:387.

3 Jílková E. Prostituce v přihraničních oblastech severních Čech vyžaduje právní i sociálně zdravotní príistup [Prostitution in border areas of North Bohemia requires law and social health attitude]. Zdravotnické noviny 1.12.2000 přiloha Lékařské listy1.12. 2000;59:3.

4 Kuklová I. Příspěvek k problematice sexuálně přenosných infekcí. Autoreferát disertační práce [Contribution to problems of sexual transmitted infections. Coreferat of thesis work]. Praha 2000:4

5 Jedlička J. Interakce HIV a ostatních pohlavně přednosných infekcí [Interaction HIV and the other STD]. Lékařské listy 1998;47:5. 